\title{
The Training Process of SMEs: What Motivates SMEs to Use E-Learning
}

\author{
doi:10.3991/ijac.v2i3.991 \\ Andrée Roy \\ Université de Moncton, Moncton, NB, Canada
}

\begin{abstract}
For centuries, traditional ways of teaching and learning were used around the world. Shifting from these well known traditional ways of teaching and learning to a more modern way - E-Learning - to adapt to the needs of the knowledge-based economies is requiring some adjustment on the part of businesses. One of these adjustments is to use e-Learning in the different phases of the training process. This research discusses the reasons which motivate SMEs to use or not to use e-Learning in the different phases of the training process.
\end{abstract}

Index Terms - e-Learning, corporate learning, reasons to use e-Learning, training processes, SMEs.

\section{INTRODUCTION}

Though theory and practice have long held a linkage between strategic human resource management (SHRM), human resource development (HRD) and organisational competitiveness and advantage, existent literature on SHRM and HRD focuses overwhelmingly on large enterprises or corporations at the expense of small and medium-sized enterprises (SMEs) despite them being identified as the fastest growing segment of the economy and being considered as the foundation of economic development $[1 ; 2]$.

In Canada, particularly in Atlantic Canada, the contribution of SMEs to a healthy economy has been recognized. They represent the majority of businesses and they also create the majority of jobs $[1 ; 3]$. Yet, despite their great contribution to the region's economy, there are very few studies on them and even less on their training process and this, notwithstanding a strategic and economic dimension to have better trained employees since that training is supposed to lead to better economic performance of enterprises.

Development capability of small firms in Atlantic Canada remains critical to economic prosperity as in other parts of the world [see for example $1 ; 4 ; 5$ ]. It is therefore important to know the training process of SMEs, to know if they use e-Learning, the training method used by very large enterprises and corporations to increase their productivity and their economic performance, as well as the reasons for which they use or do not use e-Learning in their process.

The purpose of this study is two-fold. After having identified the different phases of the training process of the SMEs, based on a survey of the documentation on the issue, the first objective is to determine, through a case study, in which of these phases the Atlantic Canada SMEs use e-Learning. The second step is to identify the reasons which motivate SMEs to use or not to use e-Learning in these phases.

\section{THEORETICAL CONTEXT}

The training process in SMEs emanates from a training function, usually under HRD, less formal and elaborated than those of larger companies. It is composed of various stages $[6 ; 7 ; 8 ; 9]$ which can be grouped around the following steps: needs analysis, methods and tools, and evaluation.

\section{A. Training needs analysis}

The training needs analysis is the first step of the training process. It consists of identifying a series of training needs through various activities $[10 ; 11]$. It must be carried out by taking into account the goals of the organization (profit, growth, quality, customer service...) [10;11; $12 ; 13 ; 14]$, its culture (policies and procedures, recruitment and hiring, current level of competence of employees and desired level, evaluation, ...) $[12 ; 14 ; 15]$, the determining factors for training needs (competition, internal problems, stakeholders, deregulation, technology, business partner ...) $[12 ; 13 ; 14]$, the needs of employees (expressed and real) $[10 ; 11 ; 13 ; 14]$, and the tasks to be carried out $[10 ; 13]$.

The analysis must be carried out before the training program is developed and this for various reasons. These reasons are: to identify specific training problems, to obtain the support of management, to develop data which will be useful in the evaluation, and finally, to determine the costs and benefits of the training [10].

There exists various methods, techniques and tools to identify training needs. They include, among other things, performance evaluation, task analysis, interviews, surveys, observation, skills matrix, document analysis (examining documents), testing, assessment by simulation, critical incidents, self-assessment, career planning, management by objectives, and sociograms $[8 ; 9 ; 10 ; 16 ; 17 ; 18 ; 19]$.

However, according to $[20 ; 21 ; 22]$, the techniques most commonly used by businesses to identify training needs are: immediate supervisor notices the need (informal technique most often used according to [23]), interviews with employees, performance evaluation, behavioral observation, surveys, group discussions, skills tests, business plan, and formal analysis of business needs. The reasons for these choices are, among others, cost, time, and ease of use.

So, the training needs analysis has to take into account several factors. It is important that this analysis be made in an adequate way $[11 ; 13 ; 24]$ since it affects the following stages of the training process [11] and that the training 
results depends on it $[11 ; 24]$. When the needs analysis is completed and the training needs are identified, one can proceed in selecting the training method, stage of the process which also plays a role in the learning outcomes.

\section{B. Training methods}

By method of training, it generally means the method that will be used in order to transmit the subject matter and to enable learning [8]. As for the transmitted subject matter, it must correspond to the needs identified during the needs analysis and the training method must be selected to ensure the training offered is effective, efficient, profitable, and interesting [25]. The objective of a training method being to facilitate the transmission of knowledge, know-how, and know-being [8].

Training methods can be formal or informal [26; 27]. The informal methods are neither planned nor documented and are unstructured $[27 ; 28]$. In contrast, formal methods are planned, structured, and documented and are offered both inside and outside companies [27;29].

Table 1 summarizes the different training methods grouped according to whether they are considered to be affirmative, interrogative or active.

Studies have been made to determine what training methods are considered the most relevant and preferred by the companies. It appears that larger companies use more formal training methods than SMEs [27]. Mentoring (one to one), conferences, seminars, and short lectures delivered in a classroom format are the training methods deemed most relevant and preferred by businesses. Some studies have also confirmed that the Internet is considered a very effective way of delivering information to different learners, as much in SMEs than in larger companies [20; $21 ; 28 ; 30]$.

TABLE I.

TRAINING METHODS

\begin{tabular}{|c|c|c|}
\hline $\begin{array}{c}\text { Affirmative meth- } \\
\text { ods }\end{array}$ & $\begin{array}{l}\text { Interrogative } \\
\text { methods }\end{array}$ & Active methods \\
\hline 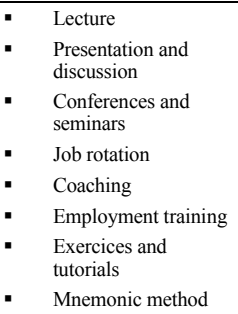 & $\begin{array}{ll}\cdot & \text { Computer-based } \\
\text { training (CBT) } \\
\cdot \quad \begin{array}{l}\text { Vestibule Training } \\
\text { (external) }\end{array} \\
\end{array}$ & $\begin{array}{ll} & \text { Case studies } \\
: & \text { Role playing } \\
: & \text { Simulation and } \\
\text { gaming } \\
: \quad & \text { Learning by doing } \\
: \quad & \text { External internship } \\
: & \text { Creativity method } \\
\text { - } & \text { In-basket }\end{array}$ \\
\hline
\end{tabular}

According to the study done by Ref. [30], 93\% of SMEs prefer the "one to one" training, i.e. that is the training directly offered to them by a trainer and this exclusively. Furthermore, $70 \%$ of SMEs prefer to receive training on demand rather than regularly scheduled.

The choice of the training method should be made according to the needs and objectives of training, the learning style of individuals who will be trained, the resources available, and the learning principles. An approach that involves a variety of methods (different types of learning), tools, and examples has a better chance of success [ 20; $21 ; 31 ; 32]$ because, as mentioned by Ref. [33], companies are made up of employees whose age and experience vary, and have different preferences regarding ways of learning, including technology.
When the training method has been chosen, you must select the tool or tools that are going to be used in the provision of the training course. The choice of tools plays an important role in the learning outcomes.

\section{Training tools}

Training tools are aids to learning and support for training [8]. They should be selected based on criteria such as the level of action required of the trainees and the trainer, the level of interaction between the trainees and between them and the trainer, the number of senses that we wish to touch through training, the ease of producing and using the tool, the cost of production and use of the tool [7], and the learning objectives pursued [34].

The tools can be grouped into four broad categories: visual tools, auditory tools, audiovisual, and interactive tools [8]. Table 2 summarizes the various tools as they are visual, auditory, audiovisual, and interactive.

TABLE II

TRAINING TOOLS

\begin{tabular}{|c|c|c|c|}
\hline $\begin{array}{l}\text { Visual } \\
\text { tools }\end{array}$ & $\begin{array}{l}\text { Auditory } \\
\text { tools }\end{array}$ & $\begin{array}{c}\text { Audiovisual } \\
\text { tools }\end{array}$ & $\begin{array}{c}\text { Interactive } \\
\text { tools }\end{array}$ \\
\hline $\begin{array}{l}\text { - } \text { Blackboard } \\
\text { - Overhead } \\
\text { projector } \\
\text { - Lecture notes } \\
\text { and explicative } \\
\text { documents }\end{array}$ & $\begin{array}{l}\text { - Tape recorder } \\
\text { - Telephone }\end{array}$ & $\begin{array}{l}\text { - Slide show } \\
\text { - Film } \\
\text { - Video tape } \\
\text { recorder }\end{array}$ & $\begin{array}{l}\text { - Computer } \\
\text { - Courseware } \\
\text { - Simulator } \\
\text { - Multimedia }\end{array}$ \\
\hline
\end{tabular}

Finally, when the training method and tools have been chosen, and the training has been given, we can proceed to the final stage of training, the evaluation of training.

\section{Training evaluation}

The evaluation consists of a set of activities that assess learning outcomes and this, both in terms of training provided to employees as the benefits that businesses derive from [11] and taking a decision on the training offered. According to Ref. [32] and Ref. [35], there are few reasons for a company to invest in training without assessing the results. This is specially true if one takes into account the fact that there is very little empirical evidence that supports what is intuitively postulated, ie that the training enhances the performance of the company $[36 ; 37 ; 38 ; 39]$ and hence has an impact on economic development [40]. However, some researchers have identified a positive relation between training and performance [20; 31; 41; 42].

There are different models for evaluating training [43] and they evaluate the results of the training offered at different levels. However, the Kirkpatrick model (Table 3) is the one most used.

TABLE III.

KIRKPATRICK'S FOUR-LEVEL MODEL

\begin{tabular}{|l|l|}
\hline \multicolumn{1}{|c|}{ Levels } & \multicolumn{1}{c|}{ Explanations } \\
\hline 1 - Reaction & $\begin{array}{l}\text { A measure of how participants feel about the various aspects of a } \\
\text { training program (satisfaction) } \\
\text { 2- Learning }\end{array}$ \\
3 - Behavior & $\begin{array}{l}\text { A measure of the knowledge acquired, skills improved, or attitudes } \\
\text { changed due to training } \\
\text { A measure of the extent to which participants change their on-the- } \\
\text { job behavior because of training (transfer) } \\
\text { A measure of the final results that occur due to training (result) }\end{array}$ \\
4- Results &
\end{tabular}

Reference [44] 
In connection with the four levels of the Kirkpatrick model, different methods may be used to evaluate training results. According to Ref. [32], the methods most used by businesses are: supervisor's reports, surveys and questionnaires, comparison between employees, development of action plans, interviews with employees, monitoring employees, case studies, simulations, and real life situations.

Further to this analysis of the training processes of businesses, it is now a question of seeing in which stages of the process SMEs use e-Learning and for which reasons.

\section{RESEARCH METHODS}

Given the present state of knowledge on e-Learning in SMEs, a qualitative and exploratory research approach was used. The case study method is well adapted in situations where theoretical propositions are few and field experience is still limited [45]. A multiple-site case study allows one to understand the particular context and evolution of each firm with regard to e-Learning. Sixteen SMEs located in the Atlantic region of Canada were studied. That is, four in each of the provinces of New Brunswick, Nova Scotia, Prince Edward Island, and Newfoundland. They were, selected to be sufficiently successful (at least 10 years in business) and representative in terms of industry and size, for theoretical generalization purposes. Following North American research [2; 46], a small enterprise (SE) is defined as having 20 to 99 employees, whereas a medium-sized one (ME) has 100 to 499.

Data were collected through semi-structured taperecorded interviews with the owner-manager or CEO and with the firm's HR manager or manager responsible for training. E-Learning users were also interviewed in four cases. Interview transcripts were then coded and analyzed following Ref. [47] prescriptions. As presented in the research results section, these firms range in size from 60 to 485 employees and operate in industries whose technological intensity varies from low to high. All export except for one firm (M). The SMEs were regrouped in four eLearning profiles of increasing intensity, based on the extent of their knowledge and use of e-Learning (none, weak, average, strong).

\section{RESEARCH RESULTS}

The study shows that the training process of SMEs emanates from a training function, as for larger companies and organizations. The training function has a formal structure in most cases (14 cases out of 16 cases) but not very elaborated. The training process includes the training needs analysis, the selection and application of training methods and tools, as well as the evaluation of training. The study also shows that the majority of SMEs use eLearning, up to a certain degree, but that some do not use it at all as shown in Table 4. This tends to confirm what is indicated by Ref. [31], i.e. that Internet and Web-based training methods are being increasingly used by SMEs and represent an "added value" as compared to conventional training methods.

A detailed study of SMEs stated knowledge about eLearning and their use of it enables us to qualify their level of use. This analysis also provides for categorizing SMEs into four distinct profiles of e-Learning users. There are SMEs that use e-Learning a great deal (strong use), those that use it quite a bit (average use), those that don't use it much (weak use), and those that don't use it at all (non-existent use) as indicated in Table 4.

TABLE IV PROFILES OF E-LEARNING'S UTILIZATION BY SMES ${ }^{1}$

\begin{tabular}{|c|c|c|c|c|}
\hline & $\begin{array}{c}\text { PROFILE I } \\
\text { STRONG } \\
(\mathrm{C}, \mathrm{D}, \mathrm{K}, \mathrm{L})\end{array}$ & $\begin{array}{c}\text { PROFILE II } \\
\text { AVERAGE } \\
(\mathrm{B}, \mathrm{E}, \mathrm{M}, \mathrm{O})\end{array}$ & $\begin{array}{c}\text { PROFILE III } \\
\text { WEAK } \\
(\mathrm{A}, \mathrm{F}, \mathrm{I}, \mathrm{J})\end{array}$ & $\begin{array}{c}\text { PROFILE IV } \\
\text { NON-EXISTENT } \\
(\mathrm{G}, \mathrm{H}, \mathrm{N}, \mathrm{P})\end{array}$ \\
\hline $\begin{array}{c}\text { SIZE } \\
\text { EMPBLRS OF }\end{array}$ & 300 TO 485 & $60 \mathrm{TO} 280$ & 150 TO 350 & 75 TO 400 \\
\hline $\begin{array}{c}\text { E-LEARNING } \\
\text { UTILIZATION }\end{array}$ & STRONG & AVERAGE & WEAK & $\begin{array}{c}\text { NON- } \\
\text { EXISTENT }\end{array}$ \\
\hline
\end{tabular}

An even more in-depth analysis of these SMEs enables us to see in which stages of the training process they use e-Learning and for which reasons.

\section{A. Training needs analysis and reasons to use e- Learning}

All SMEs who participated in the study analyze their training needs, contrary to the findings on this subject through a survey of the literature. What varies from one SME to another is the degree of formalization and rigorous (discipline) with which the analysis is carried out, if this one is made in a holistique way, which is with the aim of reaching the objectives of the company, and the level of sophistication of the tools used as indicated in Table 5. In some cases, the analysis of training needs is carried out with less discipline and fewer tools. In other cases, however, the rigorous degree with which the analysis is made is very high and the tools used, extremely sophisticated. Claude provides us with an example of this "We have a Learning Management System" (C:89-91). Denise gives us another "We use what we call a skill gap analysis supervisory road map" (D:266-268).

We observed that SMEs that make a strong use of eLearning and technologies in general, i.e. SMEs C, D, K and L (profile I), conduct much more formalized and rigorous needs analysis. They use more sophisticated tools; some even use learning management systems and other softwares. They also notice their training needs earlier. The training needs are either identified when the employees are hired or really early in the process. Claude gives us an example "The training needs analysis is done when we hire them; the analysis is done before they start to work. We have a learning management system" (C:46-48:8991). Karen gives us another "The general manager decided to include training needs in the annual business planning and in the development plan of the company. Upper management sees the importance of training and on-going training. [...] We made the analysis according to the objectives. We have software in human resources" (K:378-379:385-387). It also seems that these SMEs are more organized and systematic in the way they analyze their training needs. The analysis seems to have a specific goal, the achievement of the objectives of the company.

\footnotetext{
1 Nota: In Table 4, a "strong" use means that the business regularly uses e-learning to train its employees. An "average" use means that the business has developed at least two courses in e-learning format and that the production employees must take these courses. A "weak" use means that only few employees use it in the business and a "non-existent" use means that the business does not use e-learning to train its employees and that they do not use it to develop their knowledge.
} 
TABLE V.

FORMALIZATION, RIGOUR AND TOOLS USED TO MAKE THE TRAINING NEEDSANALYSIS

\begin{tabular}{|c|c|c|c|c|c|}
\hline Profi & & SME & $\begin{array}{c}\text { Holis- } \\
\text { tique }\end{array}$ & $\begin{array}{l}\text { Form. and } \\
\text { rigour. }\end{array}$ & Tools used \\
\hline & \multirow{4}{*}{ 粱 } & $\mathrm{C}$ & yes & high & - learning management system (LMS) \\
\hline & & D & yes & high & $\begin{array}{c}\text { - performance appraisal system - annual } \\
\text { personal development plan } \\
\text { - industrial psychologists tests } \\
\text { - skill gap analysis road map matrix } \\
\text { - performance evaluation }\end{array}$ \\
\hline & & $\mathrm{K}$ & yes & high & $\begin{array}{l}\text { - analysis of the needs of the SME } \\
\text { - different software's }\end{array}$ \\
\hline & & $\mathrm{L}$ & yes & high & - learning management system (LMS) \\
\hline \multirow{4}{*}{ 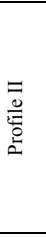 } & \multirow{4}{*}{ 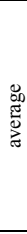 } & B & no & average & $\begin{array}{c}\text { - supervisor notices needs } \\
\text { - external evaluation: observation }\end{array}$ \\
\hline & & E & yes & high & $\begin{array}{c}\text { - tasks analysis } \\
\text { - skills analysis } \\
\cdot \text { - database } \\
\end{array}$ \\
\hline & & $\bar{M}$ & yes & average & $\begin{array}{c}\text { - management by objectives } \\
\text { - tasks analysis }\end{array}$ \\
\hline & & $\mathrm{O}$ & no & average & $\begin{array}{l}\text { - skills matrix } \\
\text { - tasks analysis }\end{array}$ \\
\hline \multirow{4}{*}{ 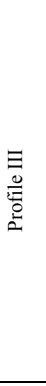 } & \multirow{4}{*}{ 觉 } & A & no & average & $\begin{array}{l}\text { - skills matrix } \\
\text { - tasks analysis }\end{array}$ \\
\hline & & F & no & low & $\begin{array}{c}\text { performance evaluation } \\
\cdot \text { annual planification (repetitive training) }\end{array}$ \\
\hline & & I & yes & average & $\begin{array}{c}\text { - survey } \\
\text { - training plan } \\
\text { - skills matrix } \\
\text { - tasks analysis } \\
\end{array}$ \\
\hline & & $\mathrm{J}$ & yes & average & $\begin{array}{c}\cdot \text { - analysis of the needs of the SME } \\
\cdot \text { development plan } \\
\cdot \text { observation } \\
\text { - group discussion (manager - supervisor } \\
- \\
\text { union representative - employee) } \\
\text { - critical incidents analysis }\end{array}$ \\
\hline \multirow{4}{*}{ 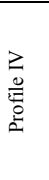 } & \multirow{4}{*}{ 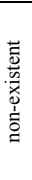 } & $\mathrm{G}$ & no & low & - performance evaluation (equipment) \\
\hline & & $\mathrm{H}$ & no & low & - performance evaluation \\
\hline & & $\mathrm{N}$ & no & low & $\begin{array}{c}\text { - tasks analysis } \\
\cdot \text { performance evaluation } \\
\end{array}$ \\
\hline & & $\mathrm{P}$ & no & low & $\begin{array}{c}\cdot \text { tasks analysis } \\
\cdot \text { observation } \\
\text { - performance evaluation }\end{array}$ \\
\hline
\end{tabular}

On the contrary, SMEs that do not use e-Learning and very little technologies, i.e. the companies $\mathrm{G}, \mathrm{H}, \mathrm{N}, \mathrm{P}$ (profile IV), conduct less highly formalized and rigorous needs analysis and the analysis is not specifically related to the achievement of the firm's objectives. They mainly use performance evaluation as a tool for the training needs analysis of employees. This tool is used either to determine if the employee can carry out, in a satisfactory way, the tasks which are assigned to him or to determine if training is needed. Whereas SMEs who make an average use of e-Learning (B, E, M, O) and those which make a weak use of it (A, F, I, J) use a variety of tools to make the training needs analysis. For this purpose, Ivan says to us: "We use a combination of tools to analyze our needs" (I:381-382). For its part, Jules says to us: "Various tools are used [...]. We also committed ourselves to the tradeunion representatives to form a united committee [...] to identify where are the gaps" (J:336-337:338-340). The formalization and the rigour of the analysis vary according to SMEs as well as the link between the analysis and the achievement of the company's objectives.

Training needs identified by SMEs are varied and depend upon each company's area of endeavour. They can be divided into two main groups: interpersonal skills (leadership, coaching, team work, effective communication, ...) and technical skills (regulatory training (pollution, environment, health and safety), computers and technologies, ...). Some SMEs encounter difficulties when they want to fulfill their training needs and some are sometimes unable to do so even when they know how. One of the benefits of e-Learning is precisely the possibil- ity of having access to training products and services that would otherwise be unavailable to SMEs.

The need to notice, when hiring or very early in the training process, the training needs of their employees is one of the reasons that motivates SMEs to use e-Learning. To ensure the achievement of the company's objectives is another reason to use e-Learning. One more reason for SMEs to use e-Learning, but not the last, is to access training which would not otherwise be available and fulfill the training needs identified.

\section{B. Training methods and reasons to use e-Learning}

SMEs in Atlantic Canada use a variety of training methods like the review of the literature showed for larger companies. They choose methods according to their training needs and sometimes depending on the supply (offer) of training that is accessible to them. These methods include mainly lectures, learning by doing as well as conferences, computer-based training (CBT), and e-Learning as shown in table 6 .

TABLE VI.

TRAINING METHODS USED BY SMES

\begin{tabular}{|c|c|c|c|c|c|c|c|c|c|c|c|c|c|c|c|c|}
\hline \multirow[t]{3}{*}{ METHODS } & \multicolumn{16}{|c|}{ SMEs } \\
\hline & \multicolumn{4}{|c|}{$\begin{array}{c}\text { Profile I } \\
\text { strong }\end{array}$} & \multicolumn{4}{|c|}{$\begin{array}{c}\text { Profile II } \\
\text { average }\end{array}$} & \multicolumn{4}{|c|}{$\begin{array}{c}\text { Profile III } \\
\text { weak }\end{array}$} & \multicolumn{4}{|c|}{$\begin{array}{c}\text { Profile IV } \\
\text { non-existent }\end{array}$} \\
\hline & $\mathrm{C}$ & $\mathrm{D}$ & $\mathrm{K}$ & L & B & E & $\mathrm{M}$ & $O$ & A & $\mathrm{F}$ & I & $\mathrm{J}$ & $\mathrm{G}$ & $\mathrm{H}$ & $\mathrm{N}$ & $\mathrm{P}$ \\
\hline \multicolumn{17}{|l|}{ Affirmative } \\
\hline \multirow{6}{*}{$\begin{array}{c}\text { lecture } \\
\text { presentation/ discus- } \\
\text { sion } \\
\text { conferences / seminars } \\
\text { job rotation } \\
\text { "coaching" } \\
\text { exercices and tutorials }\end{array}$} & $\mathrm{x}$ & $\mathrm{x}$ & $\mathrm{x}$ & $\mathrm{x}$ & $\mathrm{x}$ & $\mathrm{x}$ & $x$ & $\mathrm{x}$ & $\mathrm{x}$ & $x$ & $\mathrm{x}$ & $\mathrm{x}$ & $\begin{array}{l}X \\
2 \\
\end{array}$ & $\mathrm{x}$ & $\mathrm{x}$ & $\mathrm{x}$ \\
\hline & & $\mathrm{x}$ & $\mathrm{x}$ & & & & $\mathrm{x}$ & & & & & $\mathrm{x}$ & & $\mathrm{x}$ & & \\
\hline & $x$ & $x$ & $x$ & $x$ & & & $x$ & & & $x$ & & & & & & \\
\hline & & & & & & & & & $\mathrm{x}$ & & & & & & & $x$ \\
\hline & & & & & & & & $\mathrm{x}$ & $\mathrm{x}$ & & $\mathrm{x}$ & $\mathrm{x}$ & & & & \\
\hline & & & $x$ & & $\mathrm{x}$ & & & & & $x$ & $\mathrm{x}$ & $\mathrm{x}$ & & & & $\mathrm{x}$ \\
\hline \multirow{2}{*}{$\begin{array}{l}\text { Interrogative } \\
\text { Computer-based } \\
\text { training }\end{array}$} & & & & & & & & & & & & & & & & \\
\hline & $\mathrm{x}$ & & & $\mathrm{x}$ & $\mathrm{x}$ & & & & & & $\mathrm{x}$ & & & & & \\
\hline \multirow{6}{*}{$\begin{array}{c}\text { role playing } \\
\text { simulation and gaming } \\
\text { "learning by doing" } \\
\text { "e-Learning " }\end{array}$} & & & & & & & & & & & & & & & & \\
\hline & & $x$ & & & & & & & & & & $x$ & & & & \\
\hline & & $\mathrm{x}$ & & & & & & & $\mathrm{x}$ & & & & & & & \\
\hline & $\mathrm{x}$ & & & $\mathrm{x}$ & & & & & & & & & & & & \\
\hline & $\mathrm{x}$ & $\mathrm{x}$ & $\mathrm{x}$ & $\mathrm{x}$ & $\mathrm{x}$ & $\mathrm{x}$ & $\mathrm{x}$ & $\mathrm{x}$ & $\mathrm{x}$ & $\mathrm{x}$ & $\mathrm{x}$ & $\mathrm{x}$ & $\mathrm{x}$ & $\mathrm{x}$ & $\mathrm{x}$ & $\mathrm{x}$ \\
\hline & $\mathrm{x}$ & $\mathrm{x}$ & $x$ & $x$ & $\mathrm{x}$ & $\mathrm{x}$ & $\mathrm{x}$ & $x$ & $x$ & $x$ & $\mathrm{x}$ & $x$ & & & & \\
\hline
\end{tabular}

The method of the lecture, affirmative method, is favoured as method of training by SMEs when they have to give training in a classroom format. All SMEs that provide classroom training use this method. To this end, Omer says: "All our training dictated by the laws, such as " WHIMIS "," CPR "," First Aid " as well as certifications, is firstly given in class. We make sure that the employees know what they must do before sending them on the floor" (O: 219-223).

The "learning by doing" method, an active method, is used by all SMEs in the survey; this makes it the most frequently used by SMEs with the method of the lecture. However, the level of use varies according to SMEs and needs. For that purpose, Jules mentions: "The "learning by doing" method is frequently used to learn certain jobs. It is our preferred manner of training, and we use it since the beginnings (inception) of the company, here, in 1964" (J: 447-449). It tends to confirm what some researchers have said, which is among all the methods used, the pre-

2 This method is not used by the SME but is used by suppliers when the staff and office workers are on training abroad. 
ferred method of SMEs (owner and employees) and also the most used would be an active method, the method "learning by doing".

Some SMEs, especially those that make a strong or average use, use the e-Learning for all employee groups. To this end Karen says: "We use the e-Learning for all our employees: production workers as well as the executives" (K:661-665).

It appears that SMEs that make a strong use of eLearning use a greater variety of training methods than other SMEs. It also seems that SMEs that use e-Learning take more in consideration the learning style of their employees as Denise mentions: "The employees have the choice in the way by which they achieve their objectives, whether through traditional training or e-Learning, but, what they have no choice on is to achieve the learning objectives" (D :221-224).

SMEs which make a "weak" use of e-Learning use it only for their executive employees and office workers. An interesting fact to note, in the case of a "weak" use of eLearning by SMEs, it is usually the employee who has chosen to develop his/her knowledge through e-Learning. Jules provides an example "Some employees have chosen e-Learning, but it is usually on an exception basis, to develop their work knowledge and it was suggested by the employee and not the employer" (J:989-919).

The decision to use e-Learning by the employees in order to develop their knowledge is linked to their perceived benefits of e-Learning. Fiona provides us with an example "The employee chose this method because she wanted to continue working; she needs to work; she wanted to complete her bachelor's degree while working at the same time" (F:1026-1030). Denise gives us another example of the perceived benefits of e-Learning by the employees "Since I have a three year-old daughter and that my work schedule is rather full, I can complete the work at 3:00 AM in my slippers. Honestly, I chose e-Learning because of the flexibility" (D:82-84).

Table 7 shows each of the perceived benefits of eLearning by SMEs. The flexibility and accessibility as well as the cost are the main perceived benefits, that the eLearning is used or not used by SMEs. As for the employees, flexibility and accessibility, speed, privacy and autonomy, interactive feedback, cost, and ability to meet their learning style are the benefits that they perceive from eLearning.

The reasons for SMEs to use e-Learning are mainly related to the benefits associated with it. These benefits are: a 24 / 7 availability, a great flexibility, the possibility to test acquired knowledge and to work with new or unknown materials, an increased independence in the workplace, an increased privacy in learning, an adaptation to the individual's speed and needs, a reduction in training time, a faster upgrade and distribution of training materials, an increased training speed, a reduction of time lost from work due to training, a reduction in travel by plane, a reduction in training costs (training, meals, hotel, travel), a consistent delivery of course content compared to a teacher, the possibility of personalizing learning, and the possibilities to assess more easily the results of training.

The other perceived benefits that could encourage SMEs to use e-Learning are: the possibility of accessing training that would not be available otherwise, a fast upgrade of the employees, a reduction of stress and nervous- ness associated with the training, and the quality of courses available. The employees also see a specific benefit to e-Learning, which is the possibility of developing their knowledge and advancing their careers.

TABLE VII.

PERCEIVED BENEFITS OF E-LEARNING

\begin{tabular}{|c|c|c|c|c|c|c|c|c|c|c|c|c|c|c|c|c|}
\hline \multirow{2}{*}{$\begin{array}{c}\text { Perceived } \\
\text { benefits of } \\
\text { e-Learning }\end{array}$} & \multicolumn{10}{|c|}{$\begin{array}{c}\text { Profile I } \\
\text { strong }\end{array}$} & \multicolumn{10}{|c|}{$\begin{array}{c}\text { Profile II } \\
\text { average }\end{array}$} & \multicolumn{4}{|c|}{$\begin{array}{c}\text { Profile III } \\
\text { weak }\end{array}$} & \multicolumn{3}{c|}{$\begin{array}{c}\text { Profile IV } \\
\text { non-existent }\end{array}$} \\
\hline & C & D & K & L & B & E & M & O & A & F & I & J & G & H & N & P \\
\hline Flexibility + access. & x & x & x & x & & x & x & & x & x & x & x & x & x & x & x \\
\hline Modularity & & & x & & & x & & & & & & & & & & \\
\hline Speed & x & & x & x & & x & & & & x & x & x & x & & & \\
\hline Privacy + autonomy & & x & & & & & & & & & x & & & & & \\
\hline Interactive feedback & & x & x & & & & x & & & & & & & & & \\
\hline Cost & & & x & & & & x & & x & & x & x & x & x & x & x \\
\hline Learning style & x & x & x & x & x & & & & & & x & & & & & \\
\hline Evaluation & x & x & x & x & & x & & & & & & & & & & \\
\hline Dist. of literature & & x & & & x & & & x & & & & & & & & \\
\hline Consistent delivery & x & x & & x & & & & & & & & x & & & & \\
\hline
\end{tabular}

\section{Training tools and reasons to use e-Learning}

SMEs use a vast range of tools to train their employees. These tools are presented in Table 8 and are grouped according to the four major categories of tools cited in the literature, that is, visual, auditory, audiovisual, and interactive tools.

TABLE VIII. TRAINING TOOLS USED BY SMES

\begin{tabular}{|c|c|c|c|c|c|c|c|c|c|c|c|c|c|c|c|c|}
\hline \multirow[t]{3}{*}{ Tools } & \multicolumn{16}{|c|}{ SMES } \\
\hline & \multicolumn{4}{|c|}{$\begin{array}{c}\text { Profile I } \\
\text { strong }\end{array}$} & \multicolumn{4}{|c|}{$\begin{array}{c}\text { Profile II } \\
\text { average }\end{array}$} & \multicolumn{4}{|c|}{$\begin{array}{c}\text { Profile III } \\
\text { weak }\end{array}$} & \multicolumn{4}{|c|}{$\begin{array}{c}\text { Profile IV } \\
\text { non-existent }\end{array}$} \\
\hline & $\mathrm{C}$ & $\mathrm{D}$ & $\mathrm{K}$ & $\mathrm{L}$ & B & $\mathrm{E}$ & M & $\mathrm{O}$ & A & $\mathrm{F}$ & I & $\mathrm{J}$ & $\mathrm{G}$ & $\mathrm{H}$ & $\mathrm{N}$ & $\mathrm{P}$ \\
\hline \multirow{5}{*}{$\begin{array}{c}\text { Visual tools } \\
\text { blackboard } \\
\text { overhead projector } \\
\text { lecture notes } \\
\text { explicative documents }\end{array}$} & & & & & & & & & & & & & & & & \\
\hline & $\mathrm{x}$ & $\mathrm{x}$ & $\mathrm{x}$ & $\mathrm{x}$ & $\mathrm{x}$ & $\mathrm{x}$ & $\mathrm{x}$ & $\mathrm{x}$ & $\mathrm{x}$ & $\mathrm{x}$ & $\mathrm{x}$ & $\mathrm{x}$ & & $\mathrm{x}$ & $\mathrm{x}$ & $\mathrm{x}$ \\
\hline & $\mathrm{x}$ & $\mathrm{x}$ & $\mathrm{x}$ & $\mathrm{x}$ & $\mathrm{x}$ & $\mathrm{x}$ & $\mathrm{x}$ & $\mathrm{x}$ & $\mathrm{x}$ & $\mathrm{x}$ & $\mathrm{x}$ & $\mathrm{x}$ & & $\mathrm{x}$ & $\mathrm{x}$ & $\mathrm{x}$ \\
\hline & $\mathrm{x}$ & $\mathrm{x}$ & $\mathrm{x}$ & $\mathrm{x}$ & $\mathrm{x}$ & $\mathrm{x}$ & $\mathrm{x}$ & $\mathrm{x}$ & $\mathrm{x}$ & $\mathrm{x}$ & $\mathrm{x}$ & $\mathrm{x}$ & & $\mathrm{x}$ & $\mathrm{x}$ & $\mathrm{x}$ \\
\hline & & & & & $\mathrm{x}$ & & & $\mathrm{x}$ & $\mathrm{x}$ & & $\mathrm{x}$ & $\mathrm{x}$ & & & $\mathrm{x}$ & $\mathrm{x}$ \\
\hline \\
\hline tape recorder & & & & & & & & & & & & & & & & \\
\hline telephone & & & & & & & & & & & & & & & & \\
\hline \multicolumn{17}{|l|}{ Audiovisual tools } \\
\hline slide show & $\mathrm{x}$ & $\mathrm{x}$ & $\mathrm{x}$ & $\mathrm{x}$ & $\mathrm{x}$ & $\mathrm{x}$ & $\mathrm{x}$ & $\mathrm{x}$ & $\mathrm{x}$ & $\mathrm{x}$ & $\mathrm{x}$ & $\mathrm{x}$ & & $\mathrm{x}$ & $\mathrm{x}$ & $\mathrm{x}$ \\
\hline \multirow{2}{*}{$\begin{array}{c}\text { film (movie) } \\
\text { Video tape recorder }\end{array}$} & & $\mathrm{x}$ & & & $x$ & & & $\mathrm{x}$ & $\mathrm{x}$ & & & & & & & \\
\hline & & $\mathrm{x}$ & & & $\mathrm{x}$ & & & $\mathrm{x}$ & $\mathrm{x}$ & & & & & & & \\
\hline \multicolumn{17}{|l|}{ Interactive tools } \\
\hline \multirow{3}{*}{$\begin{array}{l}\text { computer } \\
\text { courseware } \\
\text { simulator }\end{array}$} & $\mathrm{x}$ & $\mathrm{x}$ & $\mathrm{x}$ & $\mathrm{x}$ & $\mathrm{x}$ & $\mathrm{x}$ & $\mathrm{x}$ & $\mathrm{x}$ & $\mathrm{x}$ & $\mathrm{x}$ & $\mathrm{x}$ & $\mathrm{x}$ & & $\mathrm{x}$ & $\mathrm{x}$ & $\mathrm{x}$ \\
\hline & $\mathrm{x}$ & & & $\mathrm{x}$ & $\mathrm{x}$ & $\mathrm{x}$ & & & & & $\mathrm{x}$ & & & & & \\
\hline & $\mathrm{x}$ & & & $\mathrm{x}$ & & & & & & & & & & & & \\
\hline multimedia & $\mathrm{x}$ & $\mathrm{x}$ & $\mathrm{x}$ & $\mathrm{x}$ & $\mathrm{x}$ & $\mathrm{x}$ & $\mathrm{x}$ & $\mathrm{x}$ & $\mathrm{x}$ & $\mathrm{x}$ & $\mathrm{x}$ & $\mathrm{x}$ & & & & \\
\hline e-Learning & $\mathrm{x}$ & $\mathrm{x}$ & $\mathrm{x}$ & $\mathrm{x}$ & $\mathrm{x}$ & $\mathrm{x}$ & $\mathrm{x}$ & $\mathrm{x}$ & $\mathrm{x}$ & $\mathrm{x}$ & $\mathrm{x}$ & $\mathrm{x}$ & & & & \\
\hline
\end{tabular}

As it can be seen, the training tools used by SMEs are varied and chosen depending on their needs. The tools used include the visual, audiovisual, and interactive tools. The auditory tools are used inside the other tools such as slideshows (PowerPoint). The criteria used to select the training tools are varied and are closely linked to the training method used. The ease of producing and using the tool, the cost of production and use of the tool, the learning objectives pursued, the level of qualification of the trainer, the need to provide training, the need to train in a short period of time a large number of learners and to standardize the content of the training are some selection criteria for the training tools for SMEs.

There is no difference between SMEs that use eLearning and those who do not use it in the selection of 
training tools with the exception of tools directly related to e-Learning, that is the multimedia tools.

The audiovisual tools which include, among other slide shows, movies, video, and video tape recorders are used by SMEs. Slide shows, more particularly PowerPoint, are used by virtually all SMEs. To this end Denise said: « We use PowerPoint as a presentation tool. We incorporate videos, that we filmed, in our PowerPoints » (D:523-526).

With respect to interactive tools, i.e. computers, courseware, simulators, and multimedia, they are used by the majority of SMEs. Interestingly, despite the fact that all SMEs, with the exception of one, use slide shows (PowerPoint) to train their employees, many do not mention the computer as a tool used in the training when asked what tools they are using, it is implied for them. The same phenomenon occurs for small businesses that have computers on the production floor. Moreover, SMEs (12 out of 16) who use e-Learning have mainly recourse to the interactive tools but also the visual, auditory, and audiovisual, in order to touch various senses of their employees and to increase their learning and skills. For this purpose, Denise says: «In the two courses currently being developed there will be pictures, sound, interactivity ... to ensure that employees can demonstrate their competence » (D:132-138). For its part, Omer said: "We've just installed on the production floor an on-line course. If an employee is experiencing difficulties with a process or a machine, he can go to one of the computers and view the course. The course is divided into tabs according to the processes, there is text, photos and videos » (O:665-674).

SMEs are using the tools associated with e-Learning for various reasons. They find that it allows them to use a greater variety of training tools within the same course. They also find that the tools associated with e-Learning allow them to adapt themselves to the various styles of learning of the employees and thus to improve their learning and skills level. Karen gives us a good example, saying: "We have online courses, as our courses on forklift and health and safety, all our production employees have to follow and redo them occasionally in order to get certified or re-certified. [...]They go on-line and do the courses. In the courses there is text, photos, sound, videos and at the end of the course, they must do a test, the application notes them and lets them know if they succeeded or not. [...] We also have practical evaluations » (K:103108:117-119:610-614).

\section{Evaluation and reasons to use e-Learning}

SMEs of Atlantic Canada assess the results of the training offered. However, the assessment is done formally or informally according to the training offered and the working environment. Indeed, the presence of a labor union affects how the evaluation is conducted.

SMEs use several tools to evaluate training. The choice of these tools as well as the person and the moment when the evaluation is made is closely linked to the training method used. The choice of the training method influences on whom is going to make the evaluation and how the evaluation will be made. Those who make the evaluation are the trainers, the supervisors and the managers, as well as the employees to some extent. There is no precise moment to make the evaluation. The moment is also linked to the training method. For example, the training offered by the "learning by doing" method tends to be assessed on an informal basis and actual results are recorded later. Regarding the e-Learning, SMEs that use it notice the results at more than one moment, that is, not only after but before and during training.

The reasons to evaluate are numerous and they vary according to the SMEs. The majority of SMEs evaluate more than one level of the Kirkpatrick's evaluation model as indicated in Table 9. The behavior level (the employee's use what has been learned) is the level the most evaluated followed by the reaction level (level of satisfaction with regard to the training received). SMEs that use eLearning seem more inclined to evaluate the results level, the last level of Kirkpatrick's model.

TABLE IX

LEVELS OF KIRKPATRICK'S MODEL EVALUATED BY SMES

\begin{tabular}{|c|c|c|c|c|c|c|c|c|c|c|c|c|c|c|c|c|}
\hline \multirow[t]{3}{*}{ Levels } & \multicolumn{16}{|c|}{ SMEs } \\
\hline & \multicolumn{4}{|c|}{$\begin{array}{l}\text { Profile I } \\
\text { strong }\end{array}$} & \multicolumn{4}{|c|}{$\begin{array}{l}\text { Profile II } \\
\text { average }\end{array}$} & \multicolumn{4}{|c|}{$\begin{array}{c}\text { Profile III } \\
\text { weak }\end{array}$} & \multicolumn{4}{|c|}{$\begin{array}{c}\text { Profile IV } \\
\text { non-existent }\end{array}$} \\
\hline & $\mathrm{C}$ & D & $\mathrm{K}$ & $\mathrm{L}$ & B & $\mathrm{E}$ & $\mathrm{M}$ & 0 & A & $\mathrm{F}$ & I & $\mathrm{J}$ & G & $\mathrm{H}$ & $\mathrm{N}$ & $\mathrm{P}$ \\
\hline 1 - Reaction & $\mathrm{x}$ & $\mathrm{x}$ & $\mathrm{x}$ & $\mathrm{x}$ & $\mathrm{x}$ & $\mathrm{x}$ & $\mathrm{x}$ & $\mathrm{x}$ & $\mathrm{x}$ & $\mathrm{x}$ & $\mathrm{x}$ & & & & $\mathrm{x}$ & $\mathrm{x}$ \\
\hline 2 - Learning & $\mathrm{x}$ & $\mathrm{x}$ & $\mathrm{x}$ & $\mathrm{x}$ & $\mathrm{x}$ & & $\mathrm{x}$ & & $\mathrm{x}$ & $\mathrm{x}$ & $\mathrm{x}$ & $\mathrm{x}$ & & & $\mathrm{x}$ & \\
\hline 3 - Behavior & $\mathrm{x}$ & $\mathrm{x}$ & $\mathrm{x}$ & $\mathrm{x}$ & $\mathrm{x}$ & $\mathrm{x}$ & $\mathrm{x}$ & $\mathrm{x}$ & $\mathrm{x}$ & $\mathrm{x}$ & $\mathrm{x}$ & $\mathrm{x}$ & $\mathrm{x}$ & $\mathrm{x}$ & $\mathrm{x}$ & $\mathrm{x}$ \\
\hline 4 - Results & $\mathrm{x}$ & $\mathrm{x}$ & & $\mathrm{x}$ & $\mathrm{x}$ & & & & $\mathrm{x}$ & & $\mathrm{x}$ & & $\mathrm{x}$ & & $\mathrm{x}$ & \\
\hline
\end{tabular}

Several reasons motivate the use of e-Learning. As Bert mentions it: "The training via computers speaks by itself, the person reached or didn't reach the goals » (B :459-462). The e-Learning also enables employees to redo the course or part of the course relevant to their needs when the need occurs and retest again their knowledge and skills. It also enables SMEs to adjust the training to the specific needs of the employees and to know the level of knowledge of the learners towards the contained material and this at any moment of the course. Karen gives us an example when she says: "We have online courses, for example [...] At the end of the course they must do a test, the application notes them and lets them know if they succeeded or not. They do a test at the end of each module and they must pass in order to begin the next module " (K:103-108:117-119).

The e-Learning facilitates the evaluation of training at different levels of Kirkpatrick's model (1996), specially the level 2 (what was learned) and level 3 (the use) and 4 (the results) by combining the results of e-Learning with other applications.

The e-Learning also facilitates a fairer and more constant evaluation. In addition, the e-Learning helps to know who has received training and when. It also helps ensure that everyone received the same content as mentioned by Louise: "We use a learning management system (LMS). Computers allow us to ensure that everyone received the same training» (L:45:202-205).

\section{CONCLUSION}

The study shows that the training process of SMEs emanates from a training function, as for larger companies and organizations. It includes the training needs analysis, the selection and applications of training methods and tools as well as the evaluation of training.

All SMEs who participated in the study analyze their training needs but what varies from one SME to another is the degree of formalization and the discipline with which the analysis is carried out, and the level of sophistication of the tools used. The reasons that motivate SMEs to use 
e-Learning in that phase of the training processes is the need to notice, when hiring or very early in the training process, the training needs of their employees. Another reason to use e-Learning is to ensure the achievement of the company's objectives.

SMEs in Atlantic Canada use a variety of training methods. The reasons that motivate them to use eLearning as a training method are mainly related to the benefits associated with it. These benefits are: a $24 / 7$ availability, a great flexibility, the possibility to test acquired knowledge and to work with new or unknown materials, an increased independence in the workplace, an increased privacy in learning, an adaptation to the individual's speed and needs, a reduction in training time, a faster upgrade and distribution of training materials, an increased training speed, a reduction of the time lost from work due to training, a reduction in travel by plane, a reduction in the training costs (training, meals, hotel, travel), a consistent delivery of course content compared to a teacher, the possibility of personalizing learning and the possibilities to assess more easily the results of training. The other perceived benefits that could encourage SMEs to use e-Learning are: the possibility of accessing training that would not be available otherwise, a fast upgrade of the employees, a reduction of stress and nervousness associated with the training and the quality of courses available.

A vast range of tools are used by SMEs to train their employees. They are using the tools associated with eLearning for various reasons. They find that it allows them to use a greater variety of training tools within the same course and therefore makes the training more adaptable to the various learning styles and capabilities of employees.

SMEs of Atlantic Canada also assess the results of training offered with a broad range of tools. However, the assessment is done formally or informally according to the training offered and the working environment. Therefore, SMEs who are using e-Learning use it in order to have a more formal evaluation of the training, and more rapid and accurate results of the training offered. They also use e-Learning in order to know the benefits of the training offered for the company.

\section{REFERENCES}

[1] APECA. (2005). État de la petite entreprise et de l'entrepreneurship dans la région de l'Atlantique 2005. Moncton: Direction générale des politiques et des programmes.

[2] Mittelstaedt, J.D., Harben, G.N. and Ward, W.A. (2003), How small is too small? Firm size as a barrier to exporting from the United States, Journal of Small Business Management, 41 (1), 6884. (doi:10.1111/1540-627X.00067)

[3] APECA. (1998). État de la petite entreprise et de l'entrepreneurship dans la région de l'Atlantique 1998. Moncton: Direction générale des politiques et des programmes.

[4] Matlay, H. (1999), Vocational education and training in Britain: a small business perspective, Education + Training, 41 (1), 6-13.

[5] Jayawarna, D., Macpherson, A. and Wilson, A. (2007), Training commitment and performance in manufacturing SMEs; Incidence, intensity and approaches, Journal of Small Business and Enterprise Development, 14 (2), 698-720. (doi:10.1108/146260 00710746736)

[6] Bélanger, F. and Jordan, D. H. (2000). Evaluation and Implementation of Distance Learning: Technologies and Techniques. Idea Group Publishing.
[7] Mayo, G.D. and Dubois, P.H. (1987). The complete book of training: Theory, principles and techniques. San Diego, CA: University Associates Inc.

[8] Laflamme, R. (1999). La formation en entreprise: nécessité ou contrainte? Québec: Les Presses de l'Université Laval. [9] Bolan, S. (2001). Canada behind in e-learning. Computing Canada, 27(9), 4

[9] Sekiou, L., Blondin, L., Fabi, B., Chevalier, F. and Besseyre des Horts, C.-H. (1992). Gestion des ressources humaines. Montréal: Les éditions $4 \mathrm{~L}$ inc.

[10] Brown, J. (2002). Training needs assessment: A must for developing an effective training program. Public Personnel Management, 31(4), 569-578.

[11] Cook, S. (2005a). Learning needs analysis: Part 1: What is learning needs analysis? Training Journal, January, 64-68.

[12] Cook, S. (2005b). Learning needs analysis: Part 2: Linking learning needs analysis to business. Training Journal, February, 50-54.

[13] Bailey, D. (2000). Learning needs analysis. Training Journal, April, 26-29.

[14] Fairfield-Sonn, J.W. (1987). A strategic process model for small business training and development. Journal of Small Business Management, 25(1), 11-18.

[15] Middleton, C. (2003). The rate of learning must be greater than the rate of change. Industrial and Commercial Training, 35(6/7), 306-308. (doi:10.1108/00197850310508689)

[16] Buckley, R. and Caple, J. (1990). The theory and practice of training. London: Kogan Page.

[17] Craig, R.L. (1996). The ASTD training and development handbook: A guide to human resource development $\left(4^{\text {th }}\right.$ ed.). New York, NY: McGraw-Hill ( $1^{\text {st }}$ ed. 1967).

[18] Goldstein, I.L. (1993). Training in organisations: Needs assessment, development and evaluation. Monterey, CA: Brooks/Cole Publishing Company.

[19] Soyer, J. (1998). Fonction formation. Paris: Éditions d'Organisation.

[20] Bassi, L.J. and Van Buren, M.E. (1999b). The 1999 ASTD state of the industry report. Training \& Development, 53(2), 3-27.

[21] Elbadri, A.N.A. (2001). Training practices of Polish companies: An appraisal and agenda for improvement. Journal of European Industrial Training, 25(2/3/4), 69-79.

[22] Sadler-Smith, E., Sargeant, A. and Dawson, A. (1998). Higher level skills training and SMEs. International Small Business Journal, 16(2), 84-94. (doi:10.1177/0266242698162005)

[23] Tyler, K. (1999). Brushing up on the three R's. HRMagazine, 44(10), 82-88.

[24] Redfern, M., Fairweather, R. and Watson, S. (1996). Caledonia council: A novel approach to management development. Industrial and Commercial Training, 28(5), 3-6. (doi:10.1108/00197859610122045)

[25] Hansen, C. (2006). Shopping for e-learning. The Journal of Corporate Accounting \& Finance, 12(5), 19-22.

[26] Kotey, B. and Sheridan, A. (2004). Changing HMR practices with firm growth. Journal of Small Business and Enterprise Development, 11(4), 474-485. (doi:10.1108/14626000410567125)

[27] Tanova, C. and Nadiri, H. (2005). Recruitment and training policies and practices: The case of Turkey as an EU candidate. Journal of European Industrial Training, 29(8/9), 694-711. (doi:10.1108/03090590510629830)

[28] Smith, A. and Hayton, G. (1999). What drives enterprise training? Evidence from Australia. The International Journal of Human Resource Management, 10(2), 251-272. (doi:10.1080/095851999340549)

[29] Shepherd, C.D. and Ridnour, R.E. (1996). A comparison of the sales management training practices of smaller and larger organizations. The Journal of Business \& Industrial Marketing, 11(2), 37-46. (doi:10.1108/08858629610117152)

[30] Lawless, N., Allan, J. and O'Dwyer, M. (2000). Face-to-face or distance training: Two different approaches to motivate SMEs to learn. Education \& Training, 42(4/5), 308-316. (doi:10.1108/ $\underline{00400910010347777 \text { ) }}$

[31] Bassi, L.J. and Van Buren, M.E. (1999a). Sharpening the leading edge. Training \& Development, 53(1), 23-33.

[32] Garavaglia, P.L. (1993). How to ensure transfer of training. Training \& Development, 47(10), 63-68. 


\section{The Training Process of SMEs:What MOtIVATES SMEs to USE E-LEARNING}

[33] Fry, K. (2001). E-learning markets and providers: Some issues and prospects. Education \& Training, 43(4/5), 233-239. (doi:10.1108/EUM0000000005484)

[34] Noyé, D. and Piveteau, J. (1993). Guide pratique du formateur. Paris: Insep Éditions.

[35] Jameson, S.M. (2000). Recruiting and training in small firms. Journal of European Industrial Training, 24(1), 43-50. (doi:10.1108/03090590010308255)

[36] Gibb, A.A. (1997). Small firms' training and competitiveness. Building upon the small business as a learning organisation. International Small Business Journal 15(3), 13-29.

[37] OCDE. (2002). La formation des dirigeants des PME. Paris: Éditions de l'OCDE.

[38] Patton, D., Marlow, S. and Hannon, P. (2000). The relationship between training and small firm performance: Research frameworks and lost quests. International Small Business Journal, 19(1), 11-27. (doi:10.1177/0266242600191001)

[39] Westhead, P. and Storey, D. (1996). Management training and small firm performance: Why is the link so weak? International Small Business Journal, 14(4), 13-24. (doi:10.1177/0266242 696144001)

[40] Loan-Clarke, J., Boocock, G., Smith, A. and Whittaker, J. (1999). Investment in management training and development by small businesses. Employee Relations, 21(3), 296-310. (doi:10.1108/ 01425459910273134 )

[41] Cosh, A., Duncan, J. and Hughes, A. (1998). Investing in training and small firm growth and survival: An empirical analysis for the
UK 1987-97. International Small Business Journal 17(1), 110113.

[42] McClenahen, J.S. (2004). The worrisome weight of Wall Street. Industry Week, 253(11), 46-50.

[43] Savoie, A. (1987). Le perfectionnement des ressources humaines en organisation: théories, méthodes et applications. Montréal: Les éditions Agence d'Arc inc.

[44] Kirkpatrick, D. (1996). Great ideas revisited: Techniques for evaluating training programs. Training \& Development, 50(1), 54-59.

[45] Yin, R.K. (1994), Case study research: Design and methods, $2^{\text {nd }}$ Edition, Thousand Oaks, California: Sage Publications.

[46] Wolff, J.A. and Pett, T.L. (2000), Internationalization of small firms: An examination of export competitive patterns, firm size, and export performance, Journal of Small Business Management, 38 (2), 34-47.

[47] Miles, M.B. and Huberman, A.M. (1994), Qualitative Data Analysis: An Expanded Sourcebook, $2^{\text {nd }}$ Edition, Thousand Oaks, California: Sage Publications.

\section{AUTHORS}

A. Roy is with the Universite de Moncton, Moncton, NB, Canada E1A 3E9 (E-mail : andree.roy@umoncton.ca).

This article was modified from a presentation at the ICELW 2009 conference in New York, NY, USA, June 2009. Submitted, July 2, 2009. Published as resubmitted by the author(s) on July, 31, 2009. 